\title{
The Rise of Massage and Medical Gymnastics in London and Paris before the First World War
}

\author{
Grégory Quin
}

\begin{abstract}
Massage and medical gymnastics experienced a rapid institutionalization across Europe and North America between 1850 and 1914. This article explores how this process took place in London and Paris. Physiotherapy developed many of the hallmarks of an independent discipline during this period, including an identified corpus of manipulations and exercises, some autonomous training courses and degrees for future practitioners, and even the creation of departments within several hospitals. The article analyzes all of the processes surrounding this rise, paying special attention to the influence of the ambassadors of Swedish gymnastics (which led to the re-invention of massage across Europe), to the installation of physiotherapy in hospitals in London and in Paris, and to the practical and institutional innovations driven by nurses in England and by doctors in France.
\end{abstract}

Keywords. massage, medical gymnastics, nursing, medical specialization, physiotherapy, comparative history, London, Paris

Résumé. Notre article ambitionne d'explorer l'institutionnalisation du massage et de la gymnastique médicale, entre 1850 et 1914, à Londres et à Paris en particulier, mais aussi plus largement à l'échelle de l'Europe. En effet, durant ces décennies, la physiothérapie émerge comme un domaine paramédical autonome, doté d'un corpus de manipulations et d'exercices, de filières de formation délivrant des diplômes spécifiques et même des départements hospitaliers dédiés à ces pratiques. De fait, notre ambition est d'analyser l'ensemble des processus conduisant à cette institutionnalisation nouvelle, depuis l'influence des ambassadeurs de la gymnastique suédoise - qui concourent de manière unique à la redéfinition du massage à travers l'Europe - jusqu'à l'installation de la physiothérapie dans les services hospitaliers à Londres et à Paris, mais aussi dans le cadre des innovations

Grégory Quin - Institute of Sport Science, University of Lausanne 
techniques et institutionnelles dirigées par les infirmières en Angleterre et les médecins en France.

Mots-clés. massage, gymnastique médicale, soins infirmiers, spécialisation médicale, physiothérapie, kinésthérapie, histoire comparative, Londres, Paris

\section{Introduction}

Massage and gymnastics are very ancient forms of "medical" practice and knowledge, but they seem to have attracted a renewed attention in Europe between 1850 and the First World War, as physiotherapy emerged as a recognized profession, driven in the United Kingdom by a chartered institution ${ }^{1}$ and in France by a scientific society. ${ }^{2}$ Factors explaining the rise of physiotherapy are rooted in the emergence of a Western medical modernity in the second half of the nineteenth century. ${ }^{3}$ Among other things, we can distinguish the specialization, professionalization, and the development of modern hospitals, broadly shared between the main medical fields in Europe hospitals that provided new infrastructures for physicians and their auxiliaries. ${ }^{4}$ External influences are more difficult to identify in detail as they result from the transformation of modern societies; nevertheless, the rise of massage and medical gymnastics can be linked with the changing role of women in Victorian British (and continental) societies, with the new legitimacy of physical exercise and, more broadly, with the development of new transportation opportunities, which allowed for an increase in the transfer of cultural activities. ${ }^{5}$ Certainly, the rise of Swedish gymnastics and its ambition to conquer European "markets" generated some new interests for individuals involved in the legitimation of medical, scholastic, and even military gymnastics, ${ }^{6}$ but it was also decisive in changing therapeutic modalities. $^{7}$

In France, physicians first attempted to discredit the promoters of Swedish gymnastics, not only accusing them of the "illegal practice of medicine" but also often attempting to plagiarize them and portraying their skills as being of a lower status than conventional medicine. In England, the situation was slightly different as several agents were involved since it was an open market. Thus, the development of massage and gymnastics was led by a loosely knit group of individuals, including some physicians, some Swedish gymnasts (men and women) who were training to be future teachers, and some 
nurses, who introduced massage and medical gymnastics into their hospital departments. Germany and Switzerland also took up the same issues and quickly recognized Per Henrik Ling's (17761839) Swedish gymnastics as an important stream of medical thought and practice. However, even if physicians involved themselves in the installation of orthopaedic and gymnastic clinics, ${ }^{8}$ and sometimes adopted Scandinavian practices, German gymnastics remained dominant. ${ }^{9}$

In England and France, the development of an orthopaedic "speciality," 10 which involved the diffusion of Swedish gymnastics from Stockholm to the rest of Europe, ${ }^{11}$ was also an important factor in the rise of both massage and medical gymnastics. These two practices were essentially related and combined to form the foundations of medical physiotherapy. As Margaret Palmer stated in her article in Cassell's Science and Art of Nursing, published in 1909, "the second branch [medical gymnastics] has always been supplemented by massage ... Medical gymnastics and massage are not separable; neither is complete without the other." 12

Proceeding from these key arguments and drawing on documentary evidence from different institutions (hospitals, scientific and professional societies, and so on) in France and England, this article will develop a comparative history of the institutionalization of physiotherapy in Europe, highlighting the role of Swedish gymnastics as a cultural practice transferred across national borders and between several capital cities. This comparative perspective will both enable some chronological parallels between the capitals cities of France and England and also highlight some of the broader national singularities around the interpretation of Swedish gymnastics and the institutionalization of massage and gymnastics from the middle of the nineteenth century to the eve of the First World War. ${ }^{13}$ The article aims to focus not only on what cultural transfers can produce as new and original but also on the way they affect each of the "compared" parts - parts that are presupposed to remain recognizable, despite their alteration, which has been described as the "uniqueness of different societies" by Marc Bloch in his seminal comparative work. ${ }^{14}$

\section{Swedish Roots and National Interpretations}

During the second half of the nineteenth century and until the First World War, massage and medical gymnastics attracted growing interest both from physicians and different social actors of variable professional backgrounds (masseuses, bonesetters, gymnasts, corset 
designers, and so on). This "emergence" was rooted in the alliance between orthopaedics and gymnastics, which had been established during the two decades before 1850 in France as well as in Germany and in England, ${ }^{15}$ and whose main effect was to promote the understanding of the role of muscles in human movements. ${ }^{16}$ In addition, this quite new interest appears also to have been the result of the spread of Swedish gymnastics across Europe. ${ }^{17}$

Initiated by Ling in the very first years of the nineteenth century, the method of gymnastics spread outside Sweden around 1840, when, after the death of its founder, several ambassadors among his disciples decided to go abroad trying to spread the word. In Germany, which was one of the first countries to be introduced to the new method, the advent of Swedish gymnastics initiated research about medical gymnastics, especially by Hugo Rothstein (1810-65), who was the first to use the expression "medical gymnastics" (Heilgymnastik) in the German language and who formulated the first definitions of its effective exercises. ${ }^{18}$ After Rothstein, two physicians in particular, Albert Neumann (1803-70) and Moritz Eulenburg (1811-87), used the principles of the method especially to cure chronic diseases. ${ }^{19}$

In France, Swedish gymnastics was "officially" introduced in 1847 by the publication Kinésithérapie ou Traitement des Maladies par le Mouvement, which was written by Carl August Georgii (180881). ${ }^{20}$ As an ambassador from Hjalmar Ling (1820-86), the son of Per Henrik Ling, who was then head of the Swedish National School for Gymnastics, Georgii used his book to present all of the "innovations" of Ling's method - for example, the passive movements "like pressure, frictions, percussions, massage ... ligatures, movements or attitudes." 21 Further, he also emphasized the fact that movements should replace chemical agents, which should only be used in tiny doses "destined to bring about reactions according to the law of Hahnemann! - a law which is still more recently corroborated by the numerous hydropathic and kinesitherapeutic cures that have been effected." 22

In Paris, Georgii was strongly criticized by the French orthopaedic surgeon, François Malgaigne (1806-65), which was highlighted in a review published by the British and Foreign Medico-Chirurgical Review a few years later, quoting Malgaigne: "What about all those marvellous promises? A great faith is needed to believe to them, but it will be easily accepted and recognised by 'advanced' scientists, who already adopted the fairy tales from magnetism and homeopathy."23 Following this critique, but perhaps also because of the ambivalent diffusion of homeopathy in France in the middle of the nineteenth 
century, ${ }^{24}$ Georgii did not succeed in introducing his method - or himself - in Paris. Georgii also mentions the political disorders during the revolutionary days of February 1848 to explain why he had to leave France before establishing Ling's gymnastics. ${ }^{25}$

Several months later, Georgii had relocated to London, where he published A Few Words on Kinesipathy, or Swedish Medical Gymnastics and established "an institution to develop the use of Swedish gymnastics for sick people." 26 A Few Words on Kinesipathy appears to be a kind of translation of the book he had published in Paris, but, as evidence of his success, he published a second book two years later, The Movement Cure. Again, this new book aimed to make clear the foundations and principles of the Swedish method, combining active exercises and "passive movement, based on stimulus like frictions, pressure, vibrations, ligatures, etc. point at nerves, blood vessels and internal organs."27

If Ling's Swedish gymnastics also faced some criticism in London - for example, from Archibald MacLaren (1820-84), who referred to this practice as being only "suitable for the invalid," 28 thus implying it was not adapted to healthy people - Swedish gymnastics ambassadors and promoters seem to have been better received in England (and especially in London) than in Paris, as several institutions were established. For example, the Swedish Institution for the Cure of Diseases by Manual Treatment, founded by Henrik Kellgren (1837-1916), ${ }^{29}$ was very active after 1875 , according to the prescriptions made by its director and from my consultations at the Wellcome Library. ${ }^{30}$ During the same decades, under the influence of Georgii, Dr Matthias Roth (1818-1913) "was to become the most vociferous supporter of the Swedish system," and he obtained the nomination of Concordia Löfving as the first superintendent of physical exercises for the London School Board in 1878. ${ }^{31}$

Despite the French criticism toward the Swedish method (even if the causality was not direct), ${ }^{32}$ the publication of Kinésithérapie ou Traitement des maladies par le movement in 1847 was contemporaneous with the introduction of gymnastics in hospitals in Paris under the supervision of Napoléon Laisné (1810-96), a gymnast and disciple of Colonel Amoros (1770-1848), who was the founder of a genuine French method of gymnastics. ${ }^{33}$ In Napoléon Laisnés published work, ${ }^{34}$ especially as interpreted by Jacques Monet, ${ }^{35}$ it is very clear that from the beginning this method was about gymnastics (active movements) and massage (passive movements), thus something very close to the foundation of the Swedish stream of gymnastics. Laisné himself emphasized this practical association: 


\begin{abstract}
M. Blache a, d'ailleurs, justement rappelé notre attention sur cette gymnastique passive ... qui s'est montrée si efficace à 1'Hôpital des Enfants. ... Ces effets mécaniques de pression, de frictions, de condensation, de distension des tissus ... ont été mis à profit depuis longtemps dans le nord de l'Europe, pour la cure d'un grand nombre de maladies, et en particulier la chorée ; ils font une partie essentielle de cette gymnastique suédoise, ou de Ling. ${ }^{36}$
\end{abstract}

Following these hospital experiments in Paris, three French books were published in 1863,1868 , and 1869 , emphasizing the rise of this new method of massage and all of the passive movements used to cure several pathologies. The first book was Jean Estradère's Du Massage: Son Historique, ses Manipulations, ses Effets Physiologiques et Thérapeutiques; the second volume was Napoléon Laisnés Du Massage, des Frictions et Manipulations Appliqués à la Guérison de Quelques Maladies; and, finally, the third volume was Phélippeaux's Etude Pratique sur les Frictions et le Massage. ${ }^{37}$ Based on his own experience within the Hydropathic Institute of Bagnèresde-Luchon, Estradère was well aware of the importance of Swedish gymnastics upon his activities and practices, and he began his work with an exegesis of Swedish gymnastics and its interpretation through France and Europe: "MM. Berend, Georgii, Dally and Meding emphasise that far from falling into oblivion, massage is nowadays more fashionable than ever in all the National gymnasiums in Sweden." 38

The influence of these books spread much farther than the Parisian hospitals and testified of both the diffusion of Ling's definition of gymnastics - particularly inside medical circles - and the importance of the categorization completed by Estradère, which came to be analyzed in almost all of the treatises published before the First World War in Europe. Two decades later, in his Massotherapeutics, published in 1889, the British physician William Murrell (1853-1912) pointed out that "among all the massage methods used for the stomach, the one from Laisné is the best." 39

Thus, the diffusion of Swedish gymnastics was rooted in the broader understanding of the properties of physical exercise and, thus, not only established as something "unfamiliar" but also reinvented in different local contexts. Between the lines, the main questions were about the legitimacy of the practices as well as about the conditions under which it could be delivered to patients. In France, massage and medical gymnastics were often distrusted by physicians, 
whose interests lay more in building a dominant set of practices and professions that could bring them profit, both economic and symbolic. Hence, the professor Georges Dujardin-Beaumetz (18521913) tried to impose his wording of "massothérapie" in order to anchor these practices in therapeutics and more generally in medicine. ${ }^{40}$ Similarly, William Murrell's use of the word "massotherapeutics" in the fourth edition of his work was based on the same desire, ${ }^{41}$ except that he did not want to build a reserved domain for physicians: "With massotherapeutics, [he] implies all the scientific aspects of massage, as a real therapeutics agent and not as an advertising asset for hotelkeepers in lack of customers." 42 He was attempting to root his practice in the medical field and to distance himself from certain questionable practices and colleagues.

\section{Innovation, "Scandalization," and Medicalization: Genesis of a "Profession"}

In England and France from the middle of the nineteenth century, physicians also developed a new focus on mental and nervous diseases, which were often presented as "movement" pathologies and therefore treated with therapeutics, including some active and passive exercises. ${ }^{43}$ Around 1880, hygienic and therapeutic practices became even more precise, as did a great number of pathologies that were allegedly treatable by the use of effleurage, tapotement or frictions (an interest in orthopaedics never disappeared from the minds of those physicians involved in the definition of medical gymnastics). ${ }^{44}$

In addition, the influence of Swedish gymnastics did not stop with the official introduction provided by Ling's ambassadors. Beginning in the 1880s, official tours to Stockholm were also organized by French and British scientific and medical societies - with formal governmental support - to enable individuals to discover the secret of the method for themselves and to ensure that the practices continued to spread and also to allow for some innovations.

The debates about gymnastics - the active part of the Swedish tradition - were less vigorous since it seemed that the use of moderate exercise was always good for one's health. Thus, military and school institutionalization of active gymnastics during the same period led to a better understanding of its use in medical fields. ${ }^{45}$ The development of these practices and the growing legitimacy of massage, due to the increasing number of medical reports and publications about it, demonstrates the emergence of a more structured group of practitioners, just as had been the case for teachers, 
and, hence, there was some attempt to guarantee their education. The lectures delivered by Dr Thomas Stretch Dowse at the West End Hospital for Nervous Disease, Paralysis and Epilepsy were very significant from this point of view since they were aimed "to create a class of Masseurs and Masseuses, who shall be such not only in name but in deed. Nothing can be more grotesque or ridiculous ... than to witness the abortive manner in which Massage is attempted by nurses otherwise well trained and competent." 46

In London as well as in Paris, the middle of the 1890s was critical in the emergence of a "masseuse/masseur" profession, despite the differences in how these dynamics were managed in each location. In London during summer of 1894, for instance, the British Medical Journal published an editorial condemning the "immoral massage establishments," in which activities were not always medical. ${ }^{47}$ As David Nicholls and Julianne Cheek explain, "the editorial spoke of the ease with which women and men could establish and make use of massage parlours. The implication here was that many massage establishments were merely a front for brothels and many masseurs and masseuses were simply offering massage as a euphemism for prostitution." 48

This criticism was taken up by the British press, whose repeated coverage over several weeks sensationalized the matter into a scandal that portrayed massage in public opinion to be "disguised prostitution." 49 As a consequence of this public anxiety, the editorial of the British Medical Journal suggested that the criticism of some establishments should also serve to highlight "those whose practice is legal and based upon a real certification." ${ }^{50}$ However, if the absence of a real medical, or even political, control over massage and other paramedical specialties encouraged the development of doubtful practices, some positive uses of massage also existed. For instance, in several hospitals in London, nurses were able to achieve some local certification. ${ }^{51}$ These recognized institutions were very important since "the continued study of anatomy and physiology is of great value, and every masseuse who is not a trained nurse should make herself acquainted with the best works on nursing." 52

At the same time in France, despite the continuous criticism against bonesetters and "charlatans," there was no similar public scandal over massage. Rather, the creation of the first schools of massage was much more affected by physicians' struggle to dominate paramedical practitioners; an 1892 law established that anybody lacking an official medical degree was not able to practise medicine. ${ }^{53}$ If several young physicians, like Georges Berne or Just Lucas 
Championnière (1843-1913), used (and perhaps practised) massage in their hospital departments, these manipulations were generally seen as a matter for nurses. Désiré Bourneville (1840-1909) explained the basis of his lectures given to future nurses in the Manuel Pratique de la Garde-Malade et de l'Infirmière:

Les masseurs et masseuses doivent borner leur rôle à exécuter fidèlement les prescriptions médicales, et se garder de prendre aucune espèce d'initiative. Le massage est un procédé thérapeutique excellent lorsqu'il est indiqué par la nature de la maladie. Or pour saisir ces indications, des connaissances médicales et chirurgicales très étendues sont nécessaires. Un massage hors de propos peut déterminer des accidents mortels. $^{54}$

In 1895, Paul Archambaud, a French physician, founded the Ecole Française d'Orthopédie et de Massage (EFOM). In explaining why he started this project, he began by saying that the use of massage in several hospital departments was very poor, thus he tried to impose two practices: the first one - orthopaedics - was to be reserved for the physician and the second one - massage - was to be allocated to paramedics (nurses or masseurs). It is very interesting to note that "orthopaedics," in keeping with the claims of French historians like Jacques Dufrance or Jacques Monet, continued to have considerable influence on medical gymnastics at this time. ${ }^{55}$ In fact, the earliest EFOM documents (used extensively by Monet) never cite Swedish gymnastics as having a decisive influence on its program. ${ }^{56}$ Students of this specific school, which existed outside the administration of any hospital, were physicians (who already had their degrees) and medical students who wanted to develop their knowledge and capacity. Other "vocational training" was open for the masseur, but the professional practice was very regimented and placed under strict medical supervision. Students from the EFOM had the opportunity to get some work experience in a clinic, which was connected to the Ecole, and Archambaud's ambition was to fill the void within the Faculty of Medicine with a professional role, which was becoming increasingly popular.

A couple of years before, in 1893, another school was founded by a French physician, Hector Durville (1849-1923), and it had exactly the same ambition, namely to provide a massage curriculum. However, the Ecole Pratique du Magnétisme et de Massage was soon criticized by medical authorities, which denied any legitimacy to 
the degrees delivered to these "simple" paramedics outside the official Faculty of Medicine, which then remained isolated. The consequence was that these institutions could not set professional requirements on the practice of massage or on the professional group comprised of their graduates, neither could they develop a sold definition or practical framework for the emerging profession.

Especially regarding nurses in France, the first ambition of the reformers like Bourneville was to achieve the "secularization" of nursing. Many hospitals and departments were still managed by the "soeurs hospitalières," and reformers argued that nursing education should not only depend on faith and dedication. ${ }^{57}$ In 1902, the prime minister emphasized the obligation for hospital departments to build and manage schools for future nurses. Again, the French answer was to first create the schools, which came from a clear mandate - a ministerial circular - from the central administration in Paris. ${ }^{58}$ It is also interesting to note that several schools were created outside Paris - for instance, in Bordeaux, under the supervision of a British physician, Miss Hamilton, and a British nurse, Miss Catherine Elston. ${ }^{59}$ Inspired by the Nightingale system, "doctor Hamilton and Miss Elston adapted to the French customs the material conditions and the practical trainings which had so well succeeded in England," especially as a result of the effective medical supervision over the training. ${ }^{60}$

On the other side of the channel, the answer to the 1894 scandal was not a school but, rather, a professional institution. ${ }^{61}$ The Society of Trained Masseuses was created during the winter of 1894-5 and set for itself the task of monitoring the activities of masseuses, soon establishing several principles:

- no massage to be undertaken except under medical direction,

- no "general" massage for men to be undertaken (exception may be made for urgent and nursing cases at a doctor['s] special request),

- no advertising in any but professional papers. ${ }^{62}$

In addition to these principles, the institution rapidly set some examinations for nurses who desired to achieve the new "masseuse qualification." These examinations were composed of anatomy, physiology, and some practical exercises, later augmented with elements about Swedish remedial exercises and electrotherapeutical treatments. The ambition was to create the conditions for the existence of a credible new profession, and the institution set several objectives to be achieved: 
1. To improve the training and qualifications of masseuses and to organize independent examinations for them.

2. To establish a registry for members and to form a centre of information for the public on matters connected with massage.

3. To arrange lectures, provide a good medical reference library, and afford opportunities for the discussion of subjects of interest and importance to masseuses.

4. To provide an organization to which members would have a right to apply for advice and help in professional difficulties. ${ }^{63}$

In the face of the 1894 scandal, nurses, who were already including massage in their everyday activity, especially in London hospitals, supported the initiative. ${ }^{64}$ One of the founding members of the Society of Trained Masseuses, Lucy Robinson declared just a couple of months before the publication of the British Medical Journal critiques, that she could not "speak too strongly against the idea that good massage is an easy and quickly acquired art," adding that "Swedish exercises should be studied for the use of children especially." 65

Nevertheless, and despite a large number of publications, English physicians remained somewhat sceptical about the emergence of an autonomous profession of massage. Even if some medical figures for example, Henry Hulbert - were very much interested in massage therapy, they did not really commit to developing massage before 1894. Hulbert declared, in his preface to A Manual for Students of Massage by Mary Anna Ellison, a member of the Society of Trained Masseuses, that "there can no longer be any doubt as to the utility of massage as a therapeutic agent, and any effort made towards the cure of diseases by natural means should [be] hailed with delight by the public, as well as by medical profession."66 Until 1914, this interest would grow quite quickly, particularly in several London hospitals.

\section{From the "Massage Department" in London Hospitals to Illegal Practices in France}

At the National Hospital for the Relief and Cure of the Paralysed and Epileptic as well as at teaching hospitals like Saint Bartholomew's, Saint Mary's, or Saint Thomas's, massage seems to have been used since the 1890s. There were even autonomous degrees awarded to nurses after they completed some training courses and lectures about anatomy and physiology. ${ }^{67}$ This training and local certification illustrate the logic behind the development of a modern medical field 
in England - and especially in London - based on independent hospitals, where individual initiatives were predominant. ${ }^{68}$ Georg Weisz described this process in his comparative work on medical specialization in Europe, pointing out that,

despite a huge medical resources and population, London lacked the single unified hospital or educational system within which pressure for administrative rationalization and specialization might build up. On the contrary, the system of competing private hospitals of varying sizes, with many also serving as medical schools, was fragmented, unwieldy, and, some said, wasteful. ${ }^{69}$

By contrast, in France, there was centralization around the Assistance publique - Hôpitaux de Paris, which had been the predominant institution since the beginning of the nineteenth century. ${ }^{70}$ After the foundation of the Society of Trained Masseuses, which became the Incorporated Society of Trained Masseuses in 1900, the number of official "schools of massage" seems to have increased quite quickly, following the rules set our for them and preparing nurses for their examinations. In December 1903, the National Hospital for the Relief and Cure of the Paralysed and Epileptic established a subcommittee in charge of "the question of teaching massage and electricity inside the hospital."71 During the first meeting, the subcommittee announced that it was "in favour of the Swedish system of massage and it is important to be sure that all the degrees are delivered to serious students, who will pass examinations supervised by physicians for the anatomy and physiology, after some practical demonstrations." 72 In this hospital, training classes were to begin in September 1904 and take place four times a year; each being three months long. These training sessions quickly became popular and welcomed 412 students before the First World War. ${ }^{73}$

Inside the teaching hospitals, the process seems to have been a little different. For instance, at Saint Bartholomew's, massage training courses were not located inside the hospital or under the supervision of one of its officers. There was a contract between the hospital and a Mrs Wilson, who was in charge both of a "school of massage" and an "office of masseuse" inside Saint Bartholomew's from 1907.74 Students who were in Mrs Wilson's school, which was held at York Place, were welcome in several hospital departments to do their work each afternoon, and when the training was completed they were awarded a diploma from the school and were then 
encouraged to apply for the examinations set up by the Incorporated Society of Trained Masseuses both in massage and Swedish remedial exercise. ${ }^{75}$ In fact, the situation seems quite complex as Mrs Wilson was at one point suspected of using her position inside the hospital to promote her massage training. ${ }^{76}$

At Saint Mary's, the Board of Management agreed to introduce massage for its out-patients in April 1909, and it gave the responsibility for these practices to a masseuse coming two hours each day. ${ }^{77}$ Mrs Mary Coghill-Hawkes was then appointed for $£ 130$ per year, which would be approximately $£ 14,000$ in 2015 terms, ${ }^{78}$ to give massage to all of the patients of the hospital - in the morning for the inpatients and in the afternoon for the outpatients. As CoghillHawkes had also run a "Swedish Institute" since 1904, the agreement with Saint Mary's included the possibility of her being joined by her students, when dealing with outpatients. ${ }^{79}$ Three years later, massage became an official part of the training of the nurses at Saint Mary's, in parallel with the addition of midwifery, which were both paid for by the hospital. ${ }^{80}$

At Saint Thomas's, a "Department of Physical Exercises" had existed since 1898, which combined the use of massage and physical exercises in a medical institution. ${ }^{81}$ Created for the outpatients suffering from lateral curvature of the spine, the transformation of the former consulting rooms

gave the opportunity of securing a room which could be fitted as a small gymnasium, and the Treasures and Governors on the advice of the Staff at once agreed to purchase the necessary apparatus, sanctioned the engagement of a skilled instructor to carry out a system of Swedish exercises for the lateral curvature cases, and the appointment of a clinical assistant to take charge of the department and superintend the massage and movement needed in cases of other descriptions. ${ }^{82}$

Thus, the Incorporated Society of Trained Masseuses organized classes in Swedish gymnastics from July 1900 and soon established some examination requirements in "Swedish Remedial Exercise" in $1904 .{ }^{83}$

Soon, electricity was also introduced alongside these practices, defining new borders for modern "physiotherapy," even if the word was not used in England before the First World War. In addition, it was surely at the London Hospital that the combination of massage, gymnastics, and other physical agents was most clearly 
integrated during this period, alongside other new experiences with "Syrnauer baths" and "Finsen light." ${ }^{4}$ These initiatives culminated in the creation of a specific department that gathered together all such techniques and methodologies in April 1910 and eventually was called the "physiotherapy department" after the war. ${ }^{85}$

Although several clinical or medical assistants were appointed in hospitals to manage these experiences and there was some criticism about the unregulated practice of massage, such paramedical techniques largely remained within the domain of nurses in hospitals, and this group went as far as limiting, partially and temporarily, the access of physicians (and more generally, men) to their new professional association. It is therefore interesting to emphasize that several members of the Society of Trained Masseuses were also involved in the development of midwifery during the same period. For example, Mary Rosalind Paget was successively superintendent of the Queen's Jubilee Institute for District Nursing (later known as the Queen's Nursing Institute), an advocate for new midwifery legislation, the head of the Society of Trained Masseuses, and the treasurer of the Midwives Institute. ${ }^{86}$ Such cross-over clearly indicated the logic behind the creation of a "women's guild" (or a sub-specialty in medicine or in education). The development of the Ling Physical Education Association in 1899 is an example of how an institution tried to "raise the professional status of women." 87

In France, the situation was quite different, particularly because of the less structured nursing profession - as it was for midwives or physical education teachers - until the First World War. However, several physicians and nurses were already using massage in their departments. In the four nursing schools founded in 1878 in Paris, and placed under the supervision of Bourneville, massage was soon included in the syllabus published in his Manuel Pratique de la Garde-Malade et de l'Infirmière. ${ }^{88}$ Physicians like Gustave de Frumerie also taught massage in these schools at the end of the 1890s. ${ }^{89}$

But, especially in Paris, the process was based more on science than on practice, and physicians were much more worried about their own professional status and interest inside this new field or specialty, as the creation of the Sociéte de Kinésithérapie proves. The first intentions of this organization were not only "to group together physicians interested in medical gymnastics and massage, to collect observations and experiences in these special branches of medicine and to discuss those works" but also "to study ethical and professional questions from this specific area." 90 According to the 
Revue de Cinésie et d'Electrothérapie, which published the first minutes from the Société de Kinésithérapie, the first topics discussed were concentrated on the definition of the content of the practice and its effects on the different organs and physiological systems (circulation, respiration, and so on). Dr Vuillemin, for instance, proposed a "physiological and rational classification of gymnastics":

Inspired by the principles [of] Swedish gymnastics and by the important work of our distinguished vice-president $\mathrm{M}$. Fernand Lagrange, I tried to establish a physiological classification of gymnastics and to [devise] a rational training plan for everybody, without taking age into consideration ... It seems that a Société de Kinésithérapie has to show its vitality and the strength of its principles, establishing a programme and some means of action, able to create hope, both for those who want to keep their healthy situation and those who try to regain their health. ${ }^{91}$

Besides being as a demonstration of their scientific will, it was Etienne-Jules Marey, the great physiologist, who assumed the honourary presidency of the society.

The minutes also record that ethical and professional questions were discussed, thanks to the attempts from the former students of the Ecole Pratique du Magnétisme et de Massage, who presented a petition before the National Assembly to obtain a softening of the 1892 law. Thus, the Société de Kinésithérapie, together with the Société de Médecine et de Chirurgie Pratiques de Paris, used the "prostitution" threat, following the conclusion of Dr Lièvre in his Massage et Masseurs (1904), to maintain a strict border between medicine and "quacks." In France, anxieties about massage as quasi-prostitution appeared after the creation of the professional institutions, in contrast to England. Following his book, Dr Lièvre proposed the foundation of massotherapeutics departments in Parisian hospitals, but they had already existed in London for several decades. ${ }^{92}$

Debates still continued, and a new 1906 congress in Paris about the illegal forms of medical practices tried to reaffirm the monopoly of physicians over massage practices as therapeutic applications. Medical gymnastics proponents also continued to spread their practice in hospitals, but they were confronted with a lack of both infrastructure and practitioners. Indeed, at the turn of the twentieth century, there were only "two gymnasiums in the Parisian hospitals and not even any officially recognised practitioners." 93 If these processes were influenced by Swedish gymnastics, they were also bound 
into an emerging "orthopaedic" tradition ${ }^{94}$ and, more especially, into a new neurology, leading to the first definition of "rehabilitation" based on scientific and medical knowledge. ${ }^{95}$

\section{Conclusion}

In 1915, the London County Council voted on an act concerning "establishments for massage or special treatment," which created a new legal framework for these practices while specifying that "no person shall carry on in the County of London an establishment for massage or special treatment unless the name of such person and the premises used or represented as being or intended to be used for the purpose of such establishment are registered with the Council." 96 The control over massage practices also became political, and it involved some continued fear against the "immoral purpose" of such practices. Thus, for the Incorporated Society of Trained Masseuses, it was important to become a chartered association, which was something that was achieved in July 1919. At the same time, the "members of the Ling Association ... shall be eligible to be placed upon the massage and medical gymnastic register" of the new institution, finally clarifying some parallel degrees and certifications. ${ }^{97}$

If the French development of physiotherapy has been described as an "impossible specialization," 98 the comparison with the English example allows us to point out how similar processes can succeed in different ways. ${ }^{99}$ In particular, the English case emphasizes how the absence of oppressive medical supervision allowed for the promotion and the control of paramedical practices to develop. Conversely, early French schools of physiotherapy had possibly more freedom to shape their professional and therapeutic experiences and the Société de Kinésithérapie defined the content of "kinésithérapie" for the next several decades. On both sides of the channel, hospitals played a key role in developing massage and medical gymnastics, but it seems that the autonomy of individual hospitals, in London especially, allowed more flexibility in the use and experimentation of various methods with all kinds of physical agents (pression, heat, water, electricity) and finally explains the successful rise of massage before the First World War.

In addition, Swedish gymnastics was newly recognized and used more officially as an educational aim both by the London School Board and by the National Physical Education League, where Philippe Tissié (1852-1935), using Swedish gymnastics, which he 
had discovered during a trip in Sweden at the end of the nineteenth century, emphasized the "necessity to adopt [in France] a form of physical education that was suitable for any person, social circumstance or profession." 100 Observing the minutes of the 1910 international congress organized about physiotherapy in Paris, it seems that only very few English physicians participated in the international debates. However, they were especially active in the sessions about "radiotherapy" or "electrotherapy"; disciplines in which they were more involved than in gymnastics and massage. ${ }^{101}$ This adds another interesting perspective on the history of the rise of massage and medical gymnastics, calling for some more detailed comparative work, with other European countries and with North America. In considering the history of physiotherapy, it may be interesting to further examine, in looking at the provincial hospitals both in England and France such as the experiences held by Miss Hamilton in Bordeaux, not only the increased use of physiotherapy but also to enlarge the comparison with other European countries.

\section{Acknowledgments}

The research for this article was conducted with the financial support of the Swiss National Science Foundation, under the title The Genesis and Development of British Physiotherapy (1850-1914): The Institutionalisation and Medical Specialisation of Physical Exercise' (Project no. P2LAP1_148661, 2013-2015).

\section{Notes}

1. Jane H. Wicksteed, The Growth of a Profession, Being the History of the Chartered Society of Physiotherapy, 1894-1945 (London: Edward Arnold, 1948).

2. Jacques Monet, La naissance de la kinésithérapie (Paris: Glyphe, 2009).

3. David Nicholls, "Postmodernism and Physiotherapy Research," Physical Therapy Reviews 16 (2012): 360-8.

4. Georg Weisz, "Naissance de la spécilisation médicale dans le monde germanophone," Actes de la recherche en sciences sociales 156-7 (2005): 37-51; Patrice Pinell, "La genèse du champ médical: le cas de la France (1795-1870),” Revue Française de Sociologie 50 (2009): 31549.

5. Sheila Fletcher, Women First: The Female Tradition in English Physical Education 1880-1980 (London: Athlone Press, 1984); Jacques Defrance, L'Excellence corporelle (Rennes, France: Presses Universitaires de Rennes, 1987); Frank Galligan, "The History of Gymnastic 
Activity in the West Midlands, with Special Reference to Birmingham, from 1865 to 1918: with an Analysis of Military Influences, Secular and Religious Innovation and Educational Developments," $\mathrm{PhD}$ thesis, Coventry University, 1999; Steve Bailey and Wray Vamplew, 100 Years of Physical Education 1899-1999 (London: Physical Education Association of the United Kingdom, 1999); Martin H. Geyer and Johannes Paulmann, The Mechanics of Internationalism (Oxford: Oxford University Press, 2001); Pierre-Yves Saunier, "Circulations, connexions et espaces transnationaux," Genèses 57 (2004): 110-26; Rebecca Rogers, From the Salon to the Schoolroom: Educating Bourgeois Girls in Nineteenth-Century France (University Park, PA: Pennsylvania State University Press, 2005); Katharina Rowold, The Educated Woman: Minds, Bodies, and Women's Higher Education in Britain, Germany and Spain, 1865-1914 (London: Routledge, 2010).

6. Henning Eichberg, "Body Culture and Democratic Nationalism: 'Popular Gymnastics' in Nineteenth-century Denmark," International Journal of the History of Sport 12 (1995): 108-24.

7. Anders Ottosson, "The First Historical Movements of Kinesiology: Scientification in the Bordeline between Physical Culture and Medicine around 1850," International Journal of the History of Sport 27 (2010): 1892-1919.

8. Doris Schwarzmann-Schafhauser, Orthopädie im Wandel: Die Herausbildung von Disziplin und Berufsstand in Bund und Kaiserreich (18151914) (Stuttgart: Franz Steiner Verlag, 2004).

9. Svenja Goltermann, Körper der Nation. Habitusformierung und die Politik des Turnens 1860-1890 (Göttingen, Germany: Vendenhoeck and Ruprecht, 1998).

10. Georges Vigarello, Le corps redressé: Histoire d’un pouvoir pédagogique (Paris: Delage, 1978); Roger Cooter, Surgery and Society in Peace and War: Orthopaedics and the Organization of Modern Medicine, 18801948 (London: Macmillan 1993); Georg Weisz, Divide and Conquer: A Comparative History of Medical Specialization (Oxford: Oxford University Press, 2006).

11. Gilbert Andrieu, "L'influence de la gymnastique suédoise sur l'éducation physique en France entre 1847 et 1914," Stadion 14 (1988): 163-80; Natalia Bazoge, Jean Saint-Martin, and Mickael Attali, "Promoting the Swedish Method of Physical Education throughout France for the Benefit of Public Health (1868-1954)," Scandinavian Journal of Medicine and Science in Sports 23 (2013): 232-43.

12. Margaret Palmer, "Massage," in Cassell's Science and Art of Nursing (London: Waverley Book Company, 1909), 104.

13. Thus, our ambition is also to contribute to a historiography that is far more focused on the period following the First World War. See, for instance, Ruby Heap, “Training Women for a New 'Women's 
Profession': Physiotherapy Education at the University of Toronto, 1917-40," History of Education Quarterly 35 (1995): 135-58; Beth Linker, "Strength and Science: Gender, Physiotherapy, and Medicine in the United States, 1918-35," Journal of Women's History 17 (2005): 106-32; Beth Linker, "The Business of Ethics: Gender, Medicine, and the Professional Codification of the American Physiotherapy Association, 1918-1935," Journal of the History of Medicine and Allied Sciences 60 (2005): 320-54; Alison Wrynn, "On the Margins: Therapeutic Massage, Physical Education and Physical Therapy Defining a Profession," International Journal of the History of Sport 31 (2014): 1882-95.

14. William H. Sewell, "Marc Bloch and the Logic of Comparative History," History and Theory 6, no. 2 (1967): 208-18; Michael Werner and Benedicte Zimmermann, "Beyond Comparison: Histoire croisée and the Challenge of Reflexivity," History and Theory 45 (2006): 30-50.

15. Roger Cooter, "Bones of Contention? Orthodox Medicine and the Mystery of the Bonesetter's Craft," in William F. Bynum and Roy Porter, eds., Medical Fringe and Medical Orthodoxy, 1750-1850 (London: Croom Helm, 1987), 153-83; Grégory Quin, "Genèse et structure d'un interchamp orthopédique (première moitié du 19 ème siècle): Contribution à l'histoire de l'institutionnalisation d'un champ scientifique," Revue d'bistoire des sciences 64 (2011): 323-47.

16. Rafael Mandressi, Le regard de l'anatomiste: Dissections et invention $d u$ corps en Occident (Paris: Seuil, 2003); Roger Cooter, Surgery and Society in Peace and War (about England) or by Jacques Monet, La naissance de la kinésithérapie (about France).

17. Gertrud Pfister, "Cultural Confrontations: German turnen, Swedish Gymnastics and English Sport - European Diversity in Physical Activities from a Historical Perspective," Culture, Sport, Society 6 (2003): 61-91.

18. Julia H. Von Schöler, "Über die Anfänge der Schwedischen Heilgymnastik in Deutschland - ein Beitrag zur Geschichte der Krankengymnastik im 19. Jahrhundert," $\mathrm{PhD}$ thesis, University of Munster, 2005, 61.

19. Katharina Scheel, Modelle und Praxiskonzepte der Physiotherapie: Eine Verortung innerhalb von Anthropologie und Ethik (Berlin: Lit Verlag, 2012), 114.

20. Ottosson, "The First Historical Movements of Kinesiology," 1903.

21. Carl A. Georgii, A Few Words on Kinesipathy, or Swedish Medical Gymnastics (London: Baillière, 1850), 39.

22. Carl A. Georgii, Kinésithérapie, ou Traitement des maladies par le mouvement, selon la method de Ling (Paris: Germer Baillière, 1847), 105. 
23. Anonymous, "Analytical and Critical Reviews," British and Foreign Medico-Chirurgical Review 10 (1852): 28.

24. Olivier Faure, "L'homéopathie entre contestation et integration," Actes de la recherche en sciences sociales 143 (2002): 88-96.

25. Georgii, A Few Words on Kinesipathy, 6

26. Herman Steudel, Praktik der Heilgymnastik (Stuttgart: Metzler'schen, 1860), 147.

27. Carl A. Georgii, The Movement Cure (London: Baillière, 1852), 8.

28. Archibald MacLaren, National Systems of Bodily Exercise (Oxford: Shrimpton, 1863), 6, quoted in Galligan, "The History of Gymnastic Activity," 27.

29. Anders Ottosson, "The Manipulated History of Manipulations of Spines and Joints? Rethinking Ortopaedic Medicine through the 19th Century Discourse of European Mechanical Medicine," Medicine Studies 3 (2011): 83-116.

30. Wellcome Library Archives, Henrik Kellgren's Personal Documents, Prescriptions for several patients from the Swedish Institution for the Cure of Diseases by Manual Treatment, Londres, 1875-92.

31. Bailey and Vamplew, 100 Years of Physical Education, 4.

32. In Georgii, A Few Words on Kinesipathy, Georgii emphasizes that "having been requested to lecture upon Ling's medical gymnastics at the Hôpital des Enfants Malades, and encouraged by the interest taken in [his] subject by some young physicians, [he has been] induced to undertake the treatment of some cases in order to show practically the truth of [his] doctrine" (5-6).

33. Thierry Arnal, La révolution des mouvements. Gymnastique, morale et démocratie au temps d'Amoros (1818-1838) (Paris: L'Harmattan, 2009).

34. Napoléon Laisné, Application de la gymnastique à la guérison de quelques maladies (Paris: Leclerc, 1865).

35. Monet, La naissance de la kinésithérapie.

36. Laisné, Application de la gymnastique, 192. Translated as 'M. Blache has shown the efficiency of this passive method at the Hôpital des Enfants Malades ... Its mechanical effects, coming from pressure, frictions, vibrations, ligatures ... have been used for a long time in the North of Europe, to cure a great number of diseases and especially chorea: they are a great and essential part of the Swedish gymnastics, or Ling's gymnastics.'

37. Jean Estradère, Du massage: Son histoire, ses manipulations, ses effets physiologiques et thérapeutiques (Paris: Delahaye, 1863); Laisné, Application de la gymnastique; Marie Victor Adrien Phélippeaux, Etude pratique sur les frictions et le massage, ou Guide du médecin masseur (Paris: L’Abeille médicale, 1870).

38. Estradère, Du massage, 9-10. 
39. William Murrell, Massotherapeutics or Massage as a Mode of Treatment (London: Lewis, 1889), 54.

40. Georges Dujardin-Beaumetz, L’hygiène thérapeutique: gymnastique, massage, hydrothérapie, aérothérapie, climatothérapie (Paris: Doin, 1890).

41. The three first editions are entitled Massage as a Mode of Treatment.

42. Murrell, Massotherapeutics, v.

43. Grégory Quin and Anaïs Bohuon, "Muscles, Nerves and Sex: The Contradictions of the Medical Approach to Female Bodies in Movement in France, 1847-1914," Gender and History 24 (2012): 172-86.

44. The frequent use of French words even in English books or articles is also an argument for the circulation of knowledge between the two countries.

45. David Smith, Stretching Their Bodies: The History of Physical Education (London: David and Charles, 1974); Gilbert Andrieu, La gymnastique au XIXe siècle, ou la naissance de l'éducation physique, 17891914 (Paris: Actio, 1999); Anaïs Bohuon and Antoine Luciani, "Biomedical Discourse on Women's Physical Education and Sport in France (1880-1922)," International Journal of the History of Sport 26 (2009): 573-93.

46. Thomas Dowse, The Modern Treatment of Disease by the System of Massage (London: Griffith, Farran, Okeden and Welsh, 1887), vii.

47. "Immoral 'Massage' Establishments," British Medical Journal, 14 July 1894, 88.

48. David A. Nicholls and Julianne Cheek, "Physiotherapy and the Shadow of Prostitution: The Society of Trained Masseuses and the Massage Scandals of 1894," Social Science and Medicine 62 (2006): 2340.

49. Nicholls and Cheek, "Physiotherapy and the Shadow of Prostitution," 2341.

50. "Immoral 'Massage' Establishments," 88.

51. "Hints to Masseuses," Nursing Notes, 1 May 1892, 49.

52. "Hints to Masseuses," Nursing Notes, 1 May 1892, 49.

53. Bernard Hoerni, "La loi du 30 novembre 1892," Histoire des Sciences Médicales 32 (1998): 63-8.

54. Désiré M. Bourneville, Manuel pratique de la garde-malade et de l'infirmière (Paris: Bureaux du Progrès médical, 1889), vol. 3, 269. Translated as "Masseur[s] and masseuses have to limit their role to execute medical prescriptions faithfully, and to be careful not to take any sort of initiative. Massage is an excellent therapeutic when it is indicated by the nature of the disease. Actually, to seize these indications very vast medical and surgical knowledge is necessary, and irrelevant massage can cause fatal accidents."

55. Quin, "Genèse et structure d'un interchamp orthopédique."

56. Monet, La naissance de la kinésithérapie, 278. 
57. Catherine J. Smet, "Secularization and Syndicalisation: The Rise of Professional Nursing in France, 1870-1914,” PhD thesis, University of California, 1997.

58. Geneviève Charles, L'infirmière en France d'bier à aujourd'bui (Paris: Le Centurion, 1979), 99.

59. Anna Emilie Hamilton became physician with a thesis entitled “Considérations sur les infirmières des hôpitaux," written in 1900 in Montpellier, France.

60. Charles, L'infirmière en France, 112.

61. In France, such an institution would not have existed before the First World War; the Association nationale des infirmières diplômées d'Etat was created in June 1924.

62. Chartered Society of Physiotherapy Archives (CSP Archive), Society of Trained Masseuses, Minutes of the First Official Meeting at the Midwives Institute, December 1894.

63. "Massage Notes," Nursing Notes, 1 January 1898, 12.

64. Jean Barclay, In Good Hands: The History of the Chartered Society of Physiotherapy 1894-1994 (Oxford: Heinemann, 1994), 17-18.

65. "Massage," Nursing Notes, 1 March 1894, 30.

66. Mary Anne Ellison, A Manual for Students of Massage (London: Baillière, Tilman and Cox, 1898), vii.

67. The process is the same in the Canada, especially at the University of Toronto. Ruby Heap, “Training Women for a New 'Women's Profession," 147.

68. Brian Abel-Smith, The Hospitals, 1800-1948: A Study in Social Administration in England and Wales (London: Heinemann, 1964).

69. Georg Weisz, "The Emergence of Medical Specialization in the Nineteenth Century," Bulletin of the History of Medicine 77 (2003): 562.

70. Erwin H. Ackerknecht, Medicine at the Paris Hospital, 1794-1848 (Baltimore: John Hopkins Press, 1967); Patrice Pinell, "La genèse du champ médical."

71. National Hospital for Neurology and Neurosurgery Archives (NHNN Archives), Subcommittees, Minutes from the Sub-Committee in Charge of the "Question of Massage and Electricity Teaching inside Hospital,” 10 December 1903.

72. NHNN Archives, Subcommittees, Minutes from the Sub-Committee, 17 December 1903.

73. NHNN Archives, Massage Certification Register, 1905-20.

74. Saint Bartholomew's Hospital Archives (SBH Archives), Medical Committee, Minutes, 7 August 1907.

75. SBH Archives, Memorandum about the Origins of Physiotherapy Inside the Hospital, 1912-1918, Annexe A, Letter from the honorary secretary of the medical committee, 3 June 1924. 
76. SBH Archives, Medical Committee, Minutes, 6 July 1910.

77. Saint Mary's Hospital Archives (SMH Archives), Board of Management, Minutes, 1 April 1909.

78. See http://www.bankofengland.co.uk/education/Pages/resources/inflationtools/calculator/index1.aspx (accessed 25 September 2016).

79. SMH Archives, Board of Management, Agreement between Mary Coghill-Hawkes and Saint Mary's Hospital, 16 December 1909.

80. SMH Archives, Board of Management, Minutes, 25 January 1912.

81. Anders Ottosson, "Wurde die Geschichte der Manipulation von Wirbelsäule und Gelenken Manipuliert?" Manuelle Therapie 16 (2012): 194.

82. King's College Archives, Saint Thomas's Hospital Reports, vol. 26, 1897, 195.

83. Barclay, In Good Hands, 47-8.

84. Geoffrey Storey, A History of Physical Medicine: The Story of the British Association of Rheumatism and Rebabilitation (London: Royal Society of Medicine Services, 1991).

85. London Hospital Archive, House Committee, Minutes, 25 April 1910.

86. CSP Archive, Personal Documents, Mary Rosalind Paget (18551948).

87. Bailey and Vamplew, 100 Years of Physical Education, 4.

88. Désiré M. Bourneville, Manuel pratique de la garde-malade et de l'infirmière (Paris: Bureaux du Progrès médical, 1889).

89. Gustave de Frumerie, La pratique du massage: Conférences faites aux écoles d'infirmiers et d'infirmières des hôpitaux de Paris (Paris: Vigot, 1901).

90. "Minutes of the Société de kinésithérapie de Paris," Revue de Cinésie et d'Electrothérapie, 1 January 1901, 1.

91. Charles Vuillemin, "A Physiological and Rational Classification of Gymnastics," Revue de Cinésie et d'Electrothérapie, 1 March 1901, 51.

92. L. Lièvre, Massage et Masseurs (Paris: Paulin, 1904).

93. Monet, La naissance de la kinésithérapie, 147.

94. Cooter, "Bones of Contention."

95. Glenn Gritzer and Arnold Arluke, The Making of Rehabilitation: A Political Economy of Medical Specialization, 1890-1980 (Berkeley, CA: University of California Press, 1985).

96. London Metropolitan Archives, Documents about the 1915 and 1920 Acts from the London County Council, Act on Establishments for Massage or Special Treatment, 1915.

97. CSP Archive, Documents about the Beginning of the Chartered Society of Massage and Medical Gymnastics (CSMMG), Agreement between the Ling Association and the CSMMG, 10 May 1922.

98. Jacques Monet, "Une spécialité médicale impossible: Construction et disqualification de la kinésithérapie," Regards sociologiques 29 (2005): 
115-30; Marie-Odile Frattini, "Dynamique de constitution d'une spécialité médicale fragile: la médecine de rééducation et réadaptation fonctionnelles en France entre médecine et politique," Master's thesis, Ecole des Hautes Etudes en Sciences Sociales, Paris, 2008.

99. Nicholls and Cheek, "Physiotherapy and the Shadow of Prostitution."

100. Bazoge, Saint-Martin, and Attali, "Promoting the Swedish Method," 235.

101. IIIe Congrès International de Physiothérapie: Comptes rendus et communication (Paris: Masson, 1910). 